\title{
Питирим Сорокин и его теория революции ${ }^{1}$
}

\author{
М.Ф. ЧЕРНЫШ*
}

*Михаил Федорович Черныш - доктор социологических наук, заместитель директора, Институт социологии РАН. Адрес: 117218, Москва, ул. Кржижановского, д. 24/35, к. 5. E-mail: che@isras.ru

Цитирование: Черныш М.Ф. (2017) Питирим Сорокин и его теория революции // Мир России. Т. 26. № 4. С. 71-96. DOI: 10.17323/1811-038X-2017-26-4-71-96

Российско-американский соџиолог Питирим Сорокин обобщил свои мыссли о Февральской и Октябрьской революииях в нескольких работах. В автобиографии "Длинная дорога» собраны воспоминания о том, как он присоединился к револючионному движению, вступил в партию эсеров, агитировал рабочих и крестьян за свержение царского режима. После победы Февральской революичи Сорокин стал одним из активных сторонников Временного правительства, секретарем Александра Керенского. Живые впечатления той эпохи он объединил не только в автобиографии, но и записках, в которых отражены развитие событий, стихия революционного хаоса, постепенно захвативиих Россию в 1917 году. В работе «Социология революччии» Сорокин сделал попьтку (возможно, одну из первых) создать на основе российских событий собственную теорию революиии. В ней он опирается на новейшую, с его точки зрения, теорию условных и безусловных рефлексов. В период револючии, полагал он, общество входит в состояние, когда обеспечивающце сочииальный порядок условные рефлексы перестают оказывать свое сдерживающее влияние. Социальный порядок, который поддерживается условнылми рефлексами, распадается, уступая месту стихийным, деструктивным, животным по своей природе рефлексам. Теория револючии Сорокина получила благоприятные отзывы среди его американских коллег, однако в Европе, а также в среде российской эмиграчии она рассматривалась, скорее, как антибольшевистский манифест, не имеющий серьезной научной ценности. В сорокинской теории революция представала событием, вырванным из истории и не имеющим ни предпосылок, которые создавались политикой предыдущей власти, и ни последствий не только негативного, но и позитивного свойства. Тем не менее при всех своих недостатках теория

1 Статья подготовлена при поддержке гранта РНФ №14-28-00217 «Межпоколенная социальная мобильность от XX века к XXI: четыре генерации российской истории». 
революиии Сорокина сохраняет свою иченность для российской социологии и как свидетельство эпохи, и как критика российской склонности к «историзму», заключающемуся 8 попытке отыскать ответ на сложные вопросы в стихии насильственной смены власти.

Ключевые слова: социальные изменения, революция, отношения власти, институт собственности, интегральная теория

\section{Революция как биография}

Не сразу, не при жизни, а только спустя полвека после своей смерти Питирим Сорокин занял подобающее ему место в пантеоне российской социологии. Ему возданы почести на его исторической родине в Республике Коми: сооружен монумент; памятные знаки, посвященные ему, установлены в родном селе Турья в Республике Коми и в Санкт-Петербурге, где он учился и начал преподавательскую карьеру. Сорокин, рожденный в крестьянской среде, с юных лет научился понимать и ценить ее несомненные достоинства - трудолюбие, открытость, доброту и самопожертвование. Жизненные обстоятельства заставили его самого, отца и брата вести жизнь странников, переезжающих из деревни в деревню. Невозможность оседлого образа жизни, необходимость рвать устоявшиеся дружеские связи становились для него источником постоянных переживаний. Едва обжившись в очередном селе, обретя там друзей, он должен был вместе с братом и отцом снова пускаться в дорогу в поисках заработка. Путь, на который ступил Сорокин в раннем детстве, оказался причудливо извилистым и все дальше уводил от тех мест и людей, той жизни, которые были ему столь дороги. Неслучайно один из исследователей наследия Сорокина назвал его биографию фантастической: она действительно в определенных ракурсах выглядит как сказочный нарратив о безмятежном детстве, героической юности и победной зрелости, наполненной актами восходящей мобильности [Дойков 2008, с. 2].

В итоге дорога, начавшаяся в крестьянских поселениях русского севера, вывела его за пределы отечества, сначала в Европу, а затем и в США, где сделала первым деканом факультета социологии в Гарвардском университете. Сорокин не просто самостоятельно прокладывал свой жизненный маршрут: он учился наблюдать и отличать значимое от незначимого, социальное от индивидуального, и то, что он считал важным, Сорокин делал предметом очередного исследования. Неслучайно до определенного момента движение его мысли с удивительной точностью повторяет повороты его биографии - голод, человек в экстремальных жизненных условиях, мобильность, стратификация и способы ее преодоления, границы между социальными группами, кризис нашего времени, социальная и культурная динамика. В ряду этих тем особое место занимает революция - событие, которое сыграло в его жизни решающую роль, стало той развилкой, которая вывела его за пределы России. В контексте его биографии революция - это больше, чем одиночное событие, нарушившие привычный ход жизни. Революция стала той самой фантастической подоплекой жизни - от дерзкой мечты о реформах и свободе до жестокой реальности, грозившей отнять свободу и даже жизнь, от борьбы «за» до непримиримой позиции 
«против». В юные годы Сорокин, как и его друзья, полагал, что революция принесет стране благо, что освобождение от монархических оков и отживших институтов станет началом преобразования России в свободное, демократическое государство, подобное странам Европы. Увлеченный идеей революции, он пожертвовал ради нее спокойствием и перспективой: заведомо зная, что его исключат из школы, которая сулила ему продвижение и переход в университет, он присоединился к революционерам, искренне, с полной отдачей агитировал против царской власти, участвовал в маевках и сходках, скрывался, преследуемой охранкой, в лесах, находился под арестом в тюрьме вместе с такими же, как он, идеалистами, мечтавшими построить в России справедливое общество. В воспоминаниях о мятежной юности Сорокин не давал полноценного объяснения того, почему он, сын мастерового, умело правивший оклады церковных икон, одаренный «религиозным слухом», вдруг сделался мятежником, бросившим вызов царской власти и собственной религиозности. Поворот к протесту произошел в нем в тот самый момент, когда он, получив образование, мог бы впоследствии войти в привилегированный класс, стать учителем или пойти дальше. Его мечты о социальном продвижении осуществились, но зачем было создавать угрозу собственной академической карьере? Безусловно, в становлении Сорокина как политика сыграла важную, если не решающую, роль атмосфера фронды, которая возникала в среде мыслящих, образованных людей России. Чем быстрее развивалась страна, тем шире становился круг агитировавших за радикальные социальные изменения и революцию. Можно утверждать, что российской опыт доказывал подлинность наблюдений Алексиса де Токвиля, его диагноз настроений общества накануне революции: «Даже во тьме грядущего можно обнаружить три хорошо различимых истины. Первая заключается в том, что всех людей нашего времени влечет за собой неведомая сила, которую, вероятно, можно направлять и сдерживать, но нельзя одолеть, она то слегка подталкивает их, то стремительно гонит к уничтожению аристократии; второй истиной является то, что из всех обществ в мире всегда будет особенно трудно длительное время обходиться без правительства с неограниченной властью именно тем обществам, где аристократии больше нет и быть не может; и, наконец, третья истина состоит в том, что нигде деспотизм не может иметь более губительных последствий, чем в этих самых обществах; поскольку он в большей степени, чем какой-либо другой образ правления, благоприятствует развитию всех тех пороков, к которым эти общества особенно предрасположены, а значит, побуждает их как раз к тому, к чему они и так уже были склонны по своей природе» [Токвиль 2008, с. 10]. А. Токвиль наблюдал нарастающий накануне 1789 г. дух ненависти к аристократии, готовность покончить с ее привилегиями, которая становилась чем-то вроде idea fix для французских революционеров. Но не этим ли стремлением наполнены все революции, любые социальные протесты, ставящие под вопрос существующий порядок? Всеобщее озлобление по отношению к элитам и желание разрушить созидаемое ими здание неравенства двигают революциями, они же, как полагал А. Токвиль, имеют в качестве непредсказанного последствия господство денег, победу корысти над ценностями (пусть даже обманчивыми), которые навязывает обществу аристократизированный правящий класс. Революции, наполненные высокими идеалами, создают основы для общества, ориентированного на вещный мир, в котором материальные блага становятся ценностной доминантой общественной жизни. В поисках стабильности, считал А. Токвиль, граждане, с лихвой вкусившие «радости» революции, с восторгом приветствуют авторитарную 
власть, которая, как им кажется, восстановит порядок, пусть даже и возвращая на прежнее место многие из атрибутов старого режима.

В тот период, когда Сорокин встал революционный на путь, опасности, подстерегающие постреволюционные общества, казались далекими и несущественными. Оковы авторитарной и монархической власти представлялись более предметной и ощутимой угрозой будущему. Только позже, сравнивая прежние и новые порядки, старые «сословные» и новые условия заключения, Сорокин понял, насколько мягким и «ценностно ориентированным» был царский режим: тогда в тюрьме «политических» держали вместе, не препятствуя их общению и переписке, а при случае отпускали на свободу.

«Неожиданно мой товарищ по камере, тоже неспящий, начал смеяться.

- Предполагал ли кто из нас, готовивших и приветствовавших революцию, что его арестует революционное правительство?

Мы посмеялись вместе, и я спросил Аргунова:

- Что общего у этой камеры и царской тюрьмы, где ты сидел?

- Ничего. Между ними такая же разница как между постоялым двором и первоклассным отелем.

- Ага, это и доказывает, что ты - контра» [Сорокин 1992, с. 95].

Репрессии старого режима касались условий получения образования, но создаваемые барьеры, хотя и не без труда, преодолевались. Убежденные противники царизма, в число которых входил и Сорокин, продолжали учебу в университетах, оканчивали курс, закреплялись в университетской среде и со временем могли претендовать на собственную кафедру. Старый режим был авторитарным, но не тоталитарным: академическое сообщество сохраняло в нем меру независимости от власти и оценивало не политические взгляды, а профессиональные качества претендента на вхождение в научную среду.

Если бы не мягкость режима, то не только Сорокин, но и его ранний наставник Калистрат Фалалеевич Жаков не смог бы продолжать академическую карьеру: его, также как и Сорокина, царская власть недолюбливала: он слыл богоборцем, выдвигал в противоположность православной доктрине собственную философию, отмечая при этом несовершенства социального устроения. На протяжении нескольких лет Сорокин ездил вместе с К.Ф. Жаковым в этнографические экспедиции и, вне всякого сомнения, брал на заметку некоторые общие его рассуждения. О К.Ф. Жакове Сорокин вспоминал только в своих ранних работах, но именно это позволяет сделать предположение, что влияние К.Ф. Жакова было весьма значительным для основных трудов Сорокина, написанных им уже в зрелые годы. Российский исследователь наследия Сорокина Б.Л. Рубанов отмечает, что между социальными идеями К.Ф. Жакова и Сорокина обнаруживается явное сходство [Рубанов 2003, с. 109-119]. Как и К.Ф. Жаков, Сорокин верил в то, что социальный мир находится в движении, которое следует принципу цикличности, когда цикл следует за циклом, образуя ритм социальных изменений: социальная система, трансформируясь, повторяет, хотя и в измененной форме, некоторые из прошлых этапов своего развития. Речь идет о преемственности формы, которая, однако, скрывает в себе значимые коррективы содержания. Как и К.Ф. Жаков, Сорокин допускал, что ритм развития системы может стать синкопическим, чередующим ускорения и паузы, при этом сама система, оказавшаяся во враждебной среде, может не только замедлить свое развитие, но и прекратить свое существование. Речь идет о возможной 
гибели социальной системы, заключающейся в победе хаоса над социальным порядком и постепенным распадом социальных институтов. С точки зрения К.Ф. Жакова, подобными последствиями была чревата Февральская революция 1917 г.: общество встало на путь, который строился на ложных посылах социализма и равенства, и в итоге было обречено. Но в этом пункте К.Ф. Жаков и Сорокин разошлись: видный эсер Сорокин приветствовал революцию, тем более что в период между Февралем и Октябрем он достиг пика своего политического влияния.

\section{Революция как прогресс}

Не разделяя идей К. Маркса, тяготея к социологическому идеализму, на определенном этапе своей биографии Сорокин рассматривал революцию в качестве важной стадии борьбы за демократию, за лучшее будущее для своего отечества. Старый порядок казался ему косным, достигшим, если следовать идеям цикличности, пределов своей возможной эволюции. Для Сорокина, выходца из низов, ущемление прав и свобод граждан по сословным критериям представлялось анахронизмом, затруднявшим мобильность молодого поколения: «Я превратился в активного агитатора за свержение царизма и отделения социалистов-революционеров в школе и округе. В отличие от социал-демократов эсеры были партией всех трудящихся - крестьян, рабочих, людей умственного труда. В противоположность марксистскому материализму и взглядам на человека и историю общества сквозь призму первичности экономических интересов философия и социология социалреволюционной партии были намного более идеалистичны, или, точнее, целостны. Эсеровские взгляды отводили большую роль в социальных процессах и человеческом поведении таким важным неэкономическим факторам, как созидательные идеи, личностные усилия, борьба за индивидуальность вместо марксистской борьбы за существование. Духовной близостью объясняется, почему я выбрал партию социалистов-революционеров и почему на протяжении всей последующей жизни не имел ничего общего с марксизмом» [Сорокин 1992, с. 18].

Сорокин писал автобиографию «Дальняя дорога», уже став гражданином США, и завершил ее в 1963 г., через год после Карибского кризиса, поставившего мир на грань ядерного конфликта. Любые симпатии к СССР, марксизму или левым идеям могли серьезно осложнить положение социолога-эмигранта. Именно соображениями самосохранения можно объяснить то, что Сорокин жестко отмежевывался от идей равенства и приукрасил идеологию той партии, к которой он принадлежал в России. В его интерпретации партия эсеров не имела четкой привязки к социальной структуре, объединяла в своих рядах все слои общества и ставила целью борьбу за индивидуальные свободы. В реальности эсеры принадлежали к левому крылу российской политики, представляли прежде всего интересы российского крестьянства, свято верили в преимущества общенародной собственности на землю над любыми формами частного землевладения. В предложенной ими программе развития обобществление земли должно было стать опорой для дальнейшего движения к социализму, который, с их точки зрения, был предпочтительнее, чем капиталистический рынок. Эсеры в большинстве своем действительно выступали за мирный переход от царизма к демократии (за исключением 
левого крыла), однако именно в рядах эсеров формировались боевые организации, прославившиеся громкими терактами против видных представителей правящего режима. Эсеры приветствовали Февральскую революцию и приняли активное участие в формировании Временного, переходного, правительства.

Опираясь на собственный политический опыт, Сорокин сформулировал возможные варианты социальных преобразований - консенсусный и фракционный. В первом случае социальные изменения, пусть даже в революционной форме, происходят благодаря коалиции социальных сил, которая консолидирует в своих рядах умеренные политические силы, стремящиеся к прогрессу. Широкое объединение политических партий разной окраски создает предпосылки, во-первых, для мирной смены политического режима, осознающего неспособность противостояния большинству населения и политическим движениям, которые воплощают его интересы, и, во-вторых, для демократического устройства жизни после победы. Разные политические силы, входящие в эту коалицию, образуют политические институты, априорно предполагающие возможность конкуренции за голоса избирателей. Далее политическая система продолжает свое развитие, а из программ партий, входивших в объединение, формируется умеренная, приемлемая для большинства платформа демократических преобразований. Движение к изменениям, которые опираются на одну из фракций в революционном движении (будь то левую или либеральную), несет в себе опасность масштабного революционного насилия. Революционная партия разворачивает борьбу не только против старого режима, но и против тех сил в политическом поле, которые неминуемо будут ей противостоять. Одним из итогов победы фракционного варианта становится политика репрессий по отношению к любым силам, предлагающим положиться на мнение большинства, с подавлением всяческих форм сопротивления революционной власти.

Но возможны ли в принципе консенсусные изменения и сохранение консенсуса на более поздних этапах революции? Реалистический анализ состояния общества указывает на то, что модели согласия в условиях, когда политические институты находятся в зачаточном состоянии (statu nascendi), опираются исключительно на добрую волю отдельных политических деятелей и по мере развития ситуации перерастают в жесткие конфликты, результатом которой становится победа фракционного варианта. Иными словами, сама логика революции, заключенная в сокрушении прежних политических институтов, делает консенсус неустойчивым и в итоге ведет к установлению фракционной диктатуры. Сорокин осознавал хрупкость политического режима, установившегося после Февральской революции. В своих дневниках он скрупулезно накапливал наблюдения, которые затем свел воедино в собственной теории. И эти наблюдения подсказывали ему, что локомотив революции невозможно остановить на промежуточной станции: революция заряжается энергией разрушения, которая приводит страну в состояние хаоса, а государство ставит на грань распада.

\section{Революция как кризис социальных институтов}

Течение революции Сорокин предлагал рассматривать как эволюцию механизмов социального регулирования. В нормальных условиях жизнь человека подчиняется 
инстинктам двух типов - условным и безусловным [Сорокин 2005, с. 37-40]. Безусловные рефлексы даны человеку от рождения, в них превалирует природное начало, и они, как полагал Сорокин, находятся в конфликте с условными инстинктами, обуздывавшими природу в интересах общества. Подобное деление перекликается с идеями 3. Фрейда, но, пожалуй, даже больше с идеями Ф.М. Достоевского: «Тут дьявол с Богом борется и поле битвы - сердце людей» [Достоевский 1973, с. 176]. В обычном, «нормальном» состоянии, считал Сорокин, общество способно навязать (именно навязать извне) человеку нормы цивилизованной жизни. Нарушающий эти нормы индивид становится в глазах людей злодеем, его преследуют по закону, его обрекают на то, чтобы он стал парией, отверженным во мнении окружающих его людей. В революционной ситуации ключевые социальные и политические институты (условные рефлексы, нормы поведения) оказываются в состоянии кризиса, когда нормативный базис, регулирующий поведение людей, дезинтегрирует, высвобождая безусловные, зачастую хищнические рефлексы: «Так как безусловные рефлексы гораздо сильнее условных, взятых в чистом виде, то, как общее правило, из дуэли первых и вторых выходят победителями первые. Условные рефлексы, тормозящие безусловные (если первые только не подкрепляются каким-то другим безусловным рефлексом) «гаснут», исчезают, перестают выполняться» [Сорокин 2005, с. 53]. Сорокин настаивал, повторяя это несколько раз в различных работах: цивилизующий, условный рефлекс слабее безусловного. В ситуации поединка без посредничества со стороны внешних по отношению к человеку принуждающих институтов общественные нормы перестают работать, уступая место животным инстинктам. Животная природа человека берет верх, серьезно деформируя его поведение. Однако даже в этой ситуации люди нуждаются в оправдании, поэтому победа животного начала прикрывается благими лозунгами, оправдывающими торжество хаоса и насилия: «Подавляющее большинство наших актов мы “пудрим”, одеваем в красивый костюм множества условных рефлексов, особенно речевых» [Сорокин 2005, с. 54]. Сорокин, следуя заявленной им склонности к «идеализации», психологизировал революционные изменения, рассматривая их прежде всего как трансформацию структуры массового сознания. В этом его концепция напоминает фрейдовскую теорию психодинамики как движения индивидуального сознания к установлению контроля над собственными инстинктами с той лишь разницей, что сорокинская концепция развернута в обратном направлении и констатирует утрату обществом возможности регулировать животное начало в человеке в ситуации распада социальных институтов.

В манихейском противопоставлении социального и животного Сорокин явно тяготел к реалистичному, если не сказать циничному, гоббсовскому взгляду на человека и его природу: по своей природе человек зол и эгоистичен, а социальный порядок создает ту непрочную «паутину», которая ставит поведение человека в цивилизованные рамки. В условиях коллапса хищная жажда господства и наживы берет свое, создавая бесконечную череду рисков для всех, кто вовлечен в поток изменений. Бихевиористский взгляд на поведение людей в условиях революции должен, по расчетам Сорокина, создать альтернативу идеалистическому, марксистскому взгляду на социальные изменения как скачку в будущее, эмансипацию угнетенных классов, претендующих на равенство и уважительное отношение к их интересам. Марксистский подход к революции он называл «сахарным», а тех, кто его пропагандирует, «иллюзионистами сладко-шоколадного типа». Вкладывая 
в понимание революции собственный ресентимент и свое разочарование, Сорокин оставлял без ответа ряд важнейших вопросов, вынуждающих усомниться в его концепции. Фундаментальный характер имеет вопрос о так называемой природе человека. К XX в. в общественных науках данная тема окончательно вышла из моды. Даже фрейдизм, обращающийся к неосознаваемым человеком комплексам, косвенным образом признает их социальную природу. В концепции 3. Фрейда биологическое начало рассматривается как первоматерия социального, как точка отправления к нарастающему контролю над поведением и конечному доминированию суперэго. Биологическое опосредовано социальными институтами, которые входят в природу человека в раннем детстве и становятся неотьемлемой частью его природы. Именно такое понимание институтов содержится в работах Эмиля Дюркгейма: социальные факты заключены не только во внешнем, но и внутреннем принуждении, возникающем как итог социализирующего процесса. Речь идет не об освобождении от институтов как таковых, а о тех скрытых альтернативах социальному порядку, которые латентно присутствуют в нем и находят выход в ситуации, когда общество попадает в состояние коллапса. Важные догадки на эту тему содержатся там, где Сорокин принимался размышлять о «глубине революции» и, соответственно, об укорененности существующих социальных институтов. Он полагал, что исход революции и ее последствия определяются «глубиной» привносимых ею социальных изменений и прочностью существующих социальных институтов. В данном случае «глубина» - это метафора, скрывающая отдельное направление теоретизирования. «Глубина» изменений, то есть степень изменчивости социальных институтов, находится в самой непосредственной связи со степенью встроенности в национальную почву. Можно предположить, что чем более «верхушечным» является социальный или политический порядок, тем меньше «естественного» приятия и доверия он вызывает, тем больше вероятности того, что в ходе революции он будет разрушен. По Сорокину, действительно глубинные изменения происходят в тех случаях, когда интегрированная социальная система вступает в период перехода от одного из трех выделенных им типов к другому, например, из фазы «идеациональной» (ideational) к фазе «чувственной» (sensate). Рассуждения на эту тему можно найти в его работе «Социальная и культурная динамика», где мезоуровень, на котором определяются революции в конкретных странах, соединяется с макроуровнем, на котором рассматриваются глобальные изменения в обществе, охватывающие продолжительные периоды общественной жизни [Сорокин 2006, с. 34]. В этом случае революция - это глубинный переход, в который вовлечены почти все сферы жизни общества и который связан с естественным изживанием прежнего социального порядка. В данной трактовке идея «поединка рефлексов» оказывается если не забыта полностью, то по меньшей мере отодвинута на задний план. Это дало возможность профессору Николаю Сергевичу Тимашеву, коллеге Сорокина по работе в Гарвардском университете, предположить, что на самом деле у Сорокина не одна, а две теории революции: «В действительности Сорокин использует две концепции революции, которые было бы точнее именовать как “Определение 1” и “Определение 2”. В рамках “Определения 1” он называет революцией внутреннее возмущение серьезных масштабов. Из этого определения он исключает “незначительные беспорядки” независимо от того, отвечают ли они его собственному критерию вхождения в исторические хроники, в стандартные работы по истории соответствующих стран. В “Определе- 
нии 2" он рассматривает революцию как атаку на корпус законов, которыми живет общество. В этой атаке может принимать участие значительная часть населения» [Timasheff 1963, p. 259]. В первом определении социальные возмущения индивидуализированы и не могут быть разложены на составляющие, во втором - революция становится процессом, в котором, как полагал Сорокин, несложно определить общие характеристики. Однако подбор общих и частных признаков неизбежно ведет к необходимости выделения в ряду революций разных типов. Внедрение типологии непременно заставило бы Сорокина признать русскую революцию частным случаем, лишило бы его работу той дидактической тональности, которую он старался ей придать, а также предоставило возможность для рассмотрения революции как в некоторых обстоятельствах неизбежной формы социальных изменений, но этого поворота Сорокин старался избежать. Именно из этой претензии на универсальный подход вытекает его стремление превратить русскую революции в явление эсхатологических масштабов, социальный Армагеддон, подстерегающий тех, кто соблазнился левой идеей.

\section{Последствия революции}

Николай Тимашев полагал, что Сорокин рассмотрел в революции «идеальный тип», совокупность характеристик, проявленных в ней в любом социально-экономическом контексте. Обобщая имеющиеся данные, Сорокин не смог, разумеется, занять полностью объективную позицию: слишком сильны были его чувства по отношению к той единственной революции, которая привела его в эмиграцию. Именно матрица русской революция стала для него отправной точки анализа, о чем он постоянно повторял в своих работах.

\section{Разрушение институтов власти}

Революцию, прежде всего, отличают покушение на существующую властную иерархию, стремление ее разрушить, и, как правило, этому предшествует ослабление действующей власти, которая теряет опору под ногами, но не потому, что не имеет инструментов приведения мятежного населения к порядку, а потому что утрачивает доверие и выглядит в глазах граждан как сила, действующая вопреки интересам большинства. Осознают этот факт не только противники власти, но и те, кто призван защищать ее, сохраняя социальный порядок: «С приходом революции картина резко меняется. Всякая политическая революция в первой своей стадии характеризуется угасанием громадного количества реакций повиновения у значительной части граждан. Условные связи между стимулами повиновения в лице «агентов власти» (полицейского, короля), их актов и символов, с одной стороны, и соответствующими реакциями со стороны граждан, с другой, - разрываются. На привычный стимул повиновения не следует реакция послушания, как было раньше» [Сорокин 2005, с. 205]. В подобных обстоятельствах институты власти утрачивают эффективность и проявляют нерешительность, а в рядах 
управленцев растет число колеблющихся. В результате распадается сам государственный порядок и воцаряется хаос.

Признаки распада власти Сорокин наблюдал собственными глазами по мере того, как режим, установившийся в феврале 1917 г., терял поддержку населения: «На рабочих митингах я все чаще и чаще слышу требование положить конец войне. Все чаще я слышу обвинения и даже угрозы в адрес “капиталистов”. Рабочие твердо убеждены, что все их неудачи обусловлены происками изворотливых буржуев. В народе стремительно распространяется идея о том, что правительство должно быть полностью социалистическим и что “эксплуататоров" нужно повсеместно истреблять. Все попытки инженеров и управляющих поддержать дисциплину на рабочих местах, выполнить норму заводского производства или уволить бездельников рассматриваются как контрреволюционные акции. Среди солдат ситуация не лучше. От повиновения и дисциплины фактически не осталось и следа. Солдаты слоняются без дела, не признавая никакой власти, называя себя героями, имеющими право делать, что хотят, и присваивать себе, что заблагорассудится» [Сорокин 2015, с. 70].

Монархия пала, возникли планы созыва Учредительного собрания, но условия повседневной жизни в России продолжали ухудшаться. Временное правительство, на которое работал Сорокин, могло бы остановить процесс распада, завершив войну, но оно этого не сделало: ошибочная приверженность прежнему курсу привела страну на грань полного краха. Любопытно, что за прекращение войны, бессмысленной и разрушительной, в тот момент активно выступал Макс Вебер, классик социологии, по другую сторону линии фронта. Его невозможно было упрекнуть в пацифизме, он изначально был одним из ярых сторонников войны и сожалел лишь о том, что не может быть на фронте вместе с немецкими солдатами. Однако в 1917 г. не только Россия, но и Германия оказались на грани коллапса, и М. Вебер, обладавший острой социальной интуицией, резко выступил в защиту мира. Его тревожило не только то состояние, в котором оказалось немецкое общество, но и потеря способности принимать взвешенные решения, которые обнаружил в тот период немецкий правящий класс [Кнаубе 2016, с. 485-486].

При анализе распада власти Сорокин помещал государство в страдательный контекст. По его мнению, государство, сохраняющее законность, становится той Бастилией, которую с наслаждением рушат революционеры, отпускающие на свободы деструктивные безусловные рефлексы. Однако связь между государством и революцией выглядит более сложной и запутанной, если предположить, что связь между ними отнюдь не односторонняя и страдательная. В конце концов, вполне справедливой представляется высказанная американским исследователем Дж. Фораном мысль: настоящие революции происходят только тогда и там, где функционирует современное государство, именно оно стоит у истоков политического протеста и народного возмущения. В структуралистской традиции государство выступает как важнейший субъект революции, сообщающей ей энергию действия и определяющий те рубежи, до которых могут дойти провоцируемые ею преобразования. Резюмируя структуралистские подходы, Дж. Форан называет ряд характеристик государства, содействующих переводу относительно безопасной и спокойной общественной ситуации в революционную. На первом месте стоит «государственная поддержка и спонсорство по отношению к непопулярным экономическим или социальным устройствам» [Foran 1997, p. 17]. Наибольшую 
опасность государственное покровительство представляет для тех сил, которые большинством населения рассматриваются как несправедливые. Власть обладает возможностью оказывать протекцию отдельным индивидам или целым социальным группам с помощью законодательных актов, правоохранительной деятельности, налогового законодательства, силовой мобилизации: «Люди могут винить своих непосредственных начальников за то положение, в котором они оказались, или даже целые классы, состоящие из названных начальников, но при этом хранить бережное отношение к государству (даже будучи достаточно организованными в ситуации политического благоприятствования). Но подобное бережливое отношение к государству может существовать только в том случае, если межу ним и упомянутыми элитами отсутствует симбиотическая связь. В этом смысле “правящие классы” могут быть даже в большей безопасности, если они не принимают непосредственных управленческих решений. С учетом всех обстоятельств некоторая автономия государства от господствующего экономического класса может рассматриваться как преграда на пути революции» [Foran 1997, p. 17]. В наблюдении Дж. Форана неявным образом присутствует переменная динамики отношений между государством и экономическим классом, навязывающим политику ухудшения положения широких масс населения. Если в государстве находятся силы, которые способны обуздать аппетиты экономической элиты, то революционная опасность если не исчезает полностью, то по меньшей мере отодвигается в будущее. Если же, напротив, государство становится той удобной площадкой, на которой коррумпированная элита реализует свой интерес, революционные настроения нарастают. Следует заметить, что Февральская революция почти ничего не сделала для того, чтобы отдалить государство от коррумпированных, наживавшихся на войне экономических классов. Решения по ключевым вопросам, требующим справедливости (например, по вопросу о земле), отодвигались в будущее до формирования полноценных органов власти. Однако времени на то, чтобы создать новую систему принятия легитимных решений, почти не оставалось, а ситуация продолжала ухудшаться.

Второй характеристикой государства, идущего к революции, Дж. Форан вместе с другими структуралистами считает эксклюзию «мобилизованных групп», стремящихся влиять на состояние властных институтов. Даже если подобные группы интегрируются в процесс принятия решений не полностью, а лишь частично, в их рядах неизбежно происходит раскол, способствующий дерадикализации выдвинутых требований. Политическая эксклюзия внушает противникам режима убежденность в том, что государство нереформируемо, и что только кардинальные меры могут привести к улучшению ситуации. И в этом случае возможна динамика: исключаемые из процесса активные элементы объединяются в политические «инкубаторы», превращаясь в стойких борцов с существующим режимом. В какой-то момент именно в этой категории оказался сам Сорокин, однако Февральская революция вывела его из когорты гонимых и помогла войти в круг лиц, принимающих решения. Можно только удивляться, как скоро после подобной трансформации Сорокин из радикала, борющегося с несправедливостью, превращается в защитника социального порядка и критика революционеров, остающихся на радикальных позициях.

Третья характеристика государства, призывающая революцию, - это коррумпированная, авторитарная власть, которая «отчуждает, ослабляет и разделяет 
контрреволюционную элиту» [Foran 1997, p. 20]. Примеров подобных режимов, свергнутых революциями, в истории немало ${ }^{2}$, и их ключевая проблема заключается в том, что они отталкивают от себя влиятельных игроков из числа местных политиков или даже военных. Они крайне редко имеют поддержку среднего класса и не могут опереться на него в противостоянии со своими противниками. В результате наступает момент, когда оппоненты прежней власти оказываются сильнее ее защитников. Дж. Форан неслучайно включает в число этих режимов и дореволюционную Россию: царизм славился своей коррупцией и неэффективностью, что вызывало в российском обществе повсеместное возмущение.

Излагая обстоятельства, приведшие к революции, Сорокин явно стремился снять ответственность с Временного правительства и возложить ее на большевиков. Причем Сорокин-наблюдатель вступал в спор с Сорокиным-политиком: первый видел объективные признаки социального распада и хаоса, набирающего силу, а второй подчеркивал дискретность революции, зависимость ее течения от принимаемых решений и сил, побеждающих в ней. Но где в этом наборе аргументов Сорокин-теоретик? Как представлены в дихотомии безусловных и условных рефлексов политическая линия Временного правительства, Советов или партии большевиков, рвавшихся к власти?

Революция имеет собственную логику, напрямую связанную с теми силами, которые в ней участвуют. Именно на этом понимании революционных изменений настаивал М. Вебер, внимательно следивший за революционными событиями в России. Происходившее повергало его в отчаяние, но не только потому, что события шли по трагическому сценарию нарастающего насилия. Февральскую революцию он считал «символической», ненастоящей, поскольку ни один из вопросов, которые волновали российское общество, ею решены не были: «Истинный характер режима, который возглавил Керенский, как следует уже из самого названия статьи Вебера, заключался в “символической демократии". Настоящая демократия означала бы экспроприацию земель и отказ от государственных долгов. Именно поэтому созыв Учредительного собрания был отложен. Кроме того, крестьян следовало держать на фронтах, чтобы сделать их реальное участие в выборах невозможным. Продолжение войны было необходимо в значительной степени по причинам внутриполитического характера, хотя подобная стратегия и выглядела безнадежной в перспективе» [Beetham 1985, p. 210]. Режим А.Ф. Керенского, полагал М. Вебер, держался благодаря финансовым вливаниям извне, но для того, чтобы получить деньги, председатель Временного правительства должен был отказаться от собственных идеалов и жертвовать жизнями своих граждан, продолжая войну в интересах иностранных держав. Большевизм М. Вебер считал «диктатурой капралов», подчинявшихся материальным требованиям своих сторонников [Beetham 1985, p. 232]. Большевики возглавили и направляли волну крестьянского возмущения, сметавшую слабые ростки российского капитализма. М. Beбер полагал, что эта волна сделает нереальным создание в России либерального демократического режима. Революция в силу тех компромиссов, на которые шли власти, прошла фазу, в которой было бы возможно установление в России буржуазно-демократического правительства, способного предложить обществу кон-

\footnotetext{
2 Абсолютистские монархии во Франции (Людовик XVI), России (Николай II), Иране (Пехлеви), на Кубе (Батиста), в Никарагуа (Сомоса), Румынии (Чаушеску).
} 
структивную программу развития. В отличие от Сорокина, М. Вебер анализировал события в России в «агентском» ключе как взаимодействие реальных субъектов, формирующих повестку дня - политических партий и движений в ситуации, когда диапазон принимаемых решений день ото дня сужался, провоцируя насилие.

Четвертая «ахиллесова пята» государства в его противостоянии со сторонниками радикальных изменений связана со слабостью государственной инфраструктуры и неспособностью оперативного использования насилия. В России времен Февральской революции власть не смогла заручиться поддержкой армии, которая (и это признает Сорокин) на глазах утрачивала признаки организованной силы. Иными словами, власть теряла способность управлять как раз в тот момент, когда ее собственные силовые ресурсы ослабевали. В России подобное положение складывалось всякий раз, когда страна ввязывалась во внешние военные конфликты и терпела в них поражение: в этот момент российская власть оказывалась неэффективна по нескольким направлениям одновременно - и в сфере реформ, и в военной кампании, и в усмирении восстающего общества. В записках, посвященных революции, Сорокин лишь констатировал эту повсеместную бездейственность, но не объяснял ее причины: они (и в этом нет сомнения) связаны с теми решениями, к которым он имел прямое отношение.

\section{Языковые деформации}

Говоря о языковых деформациях в период революции, Сорокин, безусловно, опередил свое время. В ситуации масштабного возмущения, охватывающего все слои населения, язык и формы описания контекста претерпевают существенные изменения. По определению Сорокина, язык людей «развязывается», его перестают «держать за зубами»: «Начинаются речи, речи без конца. Митинги и собрания, заседания и демонстрации. Широкая река газет, брошюр, листовок, плакатов, афиш затопляет страну. Словом, количественно речевые рефлексы увеличиваются» [Сорокин 2005, p. 62]. В языке набирает силу процесс десакрализации прежних святынь; в ходу хлесткая фраза, отражающая деструктивный настрой новых политических сил; речь наполняется словами, метящими в старые социальные институты. Ниспровержение сакральности приводит общество в состояние аномии, но лишь до того времени, когда вместо старых воздвигаются новые святыни и новые мученики. В этот момент, полагал Сорокин, начинается возвращение к ограничениям речевой свободы, воцаряется молчание, за которым следует языковая норма, соответствующая новой институциональной реальности. Новый языковой режим должен по необходимости содержать в себе жесткие кары за нарушение нормы: новые институты, входящие в режим интеграции, не терпят конкуренции и прибегают к болезненным санкциям, когда начинают говорить на неподобающем языке.

Языковые трансформации, описанные Сорокиным, будут позднее охарактеризованы как процесс трансформации фреймов. В этом случае речь идет об изменении смысловых координат, в которых воспринимается событие или последовательность событий. В новых координатах то, что ранее казалось твердым основанием жизни, предстает как зло, как причина кризиса, в котором оказывается 
общество. Одним из примеров трансформации является объяснение негативных тенденций в обществе интересами крупных экономических игроков. К этой стратегии широко прибегали большевики, связывавшие последствия Мировой войны с интересами мировой буржуазии, якобы стремящейся расколоть рабочее движение, заставить рабочих воевать друг с другом. Накануне Октябрьской революции лозунги прекращения войны, выдвигаемые интернационалистами в партиях социалдемократов и эсеров, вошли в противоречие с господствующим фреймом защиты национальных интересов. Подобный «перевод стрелок» из области политических решений в сферу экономических интересов мог кому-то показаться абсурдным, но именно он возобладал в той ситуации, когда большинство населения устало от войны и готово было «назначить виновного» в текущих бедах.

В согласии с концепцией Сорокина находится и теория согласования фреймов, исходящая из предположения о стремление фрейма к усилению своего влияние на счет «наведения мостов» с фреймами, задающими структуры понимания мира в иных, соседних областях жизни. Фрейм, объясняющей войну интересами буржуазии, естественным образом сопрягается с фреймом, акцентирующим преимущества равенства, а также с образом будущей жизни как счастливого избавления от пороков существующего социального порядка. В одном Сорокин, безусловно, был прав: в условиях революции согласование фреймов задает новые жесткие рамки волеизъявления, пусть даже и форме негативных и позитивных утверждений. Победившая революция в конце концов овладевает дискурсом, устанавливая и в этой сфере жесткий режим регулирования. М.Б. Ямпольский, следуя логике французского философа Анри Лефевра, утверждает, что установление новой революционной властью жестких норм невозможно рассматривать только как политическое действие. Речь идет о двухуровневой, заглубленной в культуру системе норм, способной пережить самые серьезные политические катаклизмы: «Революция, таким образом, для Анри Лефевра - это уничтожение глубинной, и от того бессознательной символической структуры, которая заменяется новыми и, если так можно выразиться, поверхностными символами (вроде “флага”). Но под этими символами, постепенно превращающими в знаки и сигналы, вновь проступает сеть глубинных архаических смыслов, знаменующих собой крушение революции» [Ямпольский 2009, с. 30]. В архаических смыслах, ищущих новое обозначение, скрывается необходимость социального порядка, который рано или поздно побеждает хаос, а старые смыслы и понятия возвращаются, хотя и в обновленной языковой оболочке.

\section{Распад этики труда}

Революция ослабляет управленческие иерархии, рождает избыточные и зачастую ложные смыслы по отношению к будущему, способствуя тем самым распаду этических норм в сфере труда. Сорокин исходил из того, что в естественном состоянии человек старается избежать необходимости трудиться и стремится к тому, чтобы получить все, что ему нужно, не прилагая для этого усилий. Но для того чтобы леность не взяла верх над обязательностью труда, общество вырабатывает то, что Сорокин называл «тормозами лености». Если же «тормоза лености» (нормы, при- 
нуждающие человека трудиться) отказывают, то человек перестает работать или работает спустя рукава. В результате само существования общества оказывается под угрозой, а новая революционная власть обязана заставить рабочих вернуться к станкам, забыть о своих прежних требованиях нормирования труда и более высокой оплаты. Под видом новой трудовой этики работникам навязывается идеология самоотдачи, трудового героизма, трудового подвига по имя счастливого будущего - «через четыре года здесь будет город-сад». Эксплуатация, которую планировалось отменить в ходе революции, возвращается в утроенной форме, причем без всяких исключений. Новая власть, независимо от ее идеологии, прибегает к крайней степени принуждения к труду, ставя себе на службу такие инструменты, как угроза голода или страх смерти.

В описании эволюции ценностей труда в ходе революции Сорокин оставался верен бихевиористским подходам: труд он рассматривал только как деятельность, которой необходимо внешнее принуждение. Только устойчивый социальный порядок способен создавать подобные стимулы, но в то же время революции, разрушающие порядок, напротив, ликвидируют сами основы трудовой деятельности. В трудах Сорокина подобная тенденция иллюстрируется таблицами, свидетельствующими о падении производительности труда в период народных возмущений, но можно ли их считать бесспорным доказательством тезиса о распаде самой этики труда [Сорокин 2005, с. 92-93]? В конце концов, речь идет о кризисе институтов и связанных с ними организаций, а кризис организации - это неизбежное разрушение управленческих иерархий и коммуникационных связей, отлаженных в мирный период жизни.

Сорокин выражал недоверие идее уничтожения в обществе праздных классов путем революции: «Так снова и снова повторяется в истории “урок” людям: одним - праздным - говорящим, что своим паразитизмом они вызывают справедливое негодование и бурю революции, которая и уничтожит их или их потомков; другим - обремененным трудом - что меньше всего кроваво-революционным путем можно облегчить бремя труда. Этот метод не годен» [Сорокин 2005, с. 100]. Ликвидация прежнего праздного класса становится для последнего запоздалым уроком, его ниша в структуре общества заполняется другими людьми, но эта селекция носит отрицательный характер, и новый праздный класс неизменно хуже и опаснее старого. Его жертвой, полагал Сорокин, становятся люди труда, которым в новых условиях не легче, а, напротив, намного тяжелее прежнего, и за свое увлечение идеей слома старой системы они платят слишком высокую цену в форме крайних форм принуждения и бесправия.

В пылу полемики Сорокин часто переходил грань между социологической и политической аргументацией, отдалялся от принципа объективности, которому, как исследователь, должен был следовать. Он, один из создателей теории социальной мобильности, совершенно забывал о том, что революция - это, помимо всего прочего, разрушение барьеров сословности и огромные возможности для выходцев из низов достигнуть высоких позиций в системе управления, получить образование, заняться умственным трудом, выйти за географические границы, которые установлены прежней властью. Революция создает свободу для социального экспериментирования и новых форм трудовой организации. Американский социолог Уильям Сьюелл, изучавший последствия французской революции 1830 г., отметил в качестве одного из ее эффектов становление классового сознания 
у рабочих, появление у них собственных газет и журналов и, как следствие, возникновение новых форм самоорганизации: «Рабочие использовали двусмысленность либерального дискурса для того, чтобы утвердить язык рабочих объединений в другой, гораздо более практической сфере. Начиная с 1831 года рабочие разных профессий начали превращать свои корпоративные организации в ассоциации, обосновывая это действие риторически как проявление свободы, которую прокламировал новый режим» [Sewell 1980, p. 204]. Новые типы объединения ассимилировали некоторые старые формы (кассы взаимопомощи), освобожденные от религиозной оболочки, но, кроме того, они повсеместно создавали комитеты, ставившие целью существенно влиять на отношения между собственниками и работниками, регулировать найм и увольнение, уровень заработной платы и ее колебания. Иными словами, одним из непреднамеренных последствий революции и ее риторики свободы стало возникновение протопрофсоюзов, которые, как известно, впоследствии превратились в один из важных институтов, защищающих права рядовых работников и приводящих трудовые отношения в состояние, близкое к современному. Парадоксально, но революция, выдвигавшая левые лозунги, создала основу для формирования одного из основополагающих институтов свободной рыночной системы.

\section{Распад отношений собственности}

Одним из последствий революции Сорокин называл кризис ключевого института общественной жизни - собственности. В обществе, объятом народными волнениями, собственность перестает быть священной: «С объективной точки зрения деформация рефлексов собственности на первой стадии революции состоит в следующем: а) в отпадении тормозящих захват чужой собственности условно-собственнических рефлексов у лиц бедных, с “ущемленными” и неудовлетворенными собственническими рефлексами; б) в силу этого - в проявлении у них безусловных рефлексов собственности (в форме захвата чужого состояния), прежде тормозимых отпавшими теперь условными рефлексами; в) у лиц богатых - в угасании и ослаблении рефлексов защиты своей собственности от посягательств других» [Сорокин 2005, с. 103]. Согласно Сорокину, в период революции атака на существующие отношения собственности связана, как правило, со стремлением к ее перераспределению. «Низы» общества, обездоленные существующим порядком, получают возможность в полной мере реализовать свое стремление к справедливости, однако справедливость не наступает, а собственность, изъятая у прежних владельцев, присваивается новой элитой, при этом «низам» достается лишь прежняя или даже меньшая доля общественного богатства. Отношения собственности, как и отношения в сфере политики в революционный период, следует рассматривать как трехфазный цикл, завершающийся примерно в той точке, с которой он начался.

Сорокин видел в навеянной революцией дискуссии о собственности недопустимую поверхностность и манипуляцию общественным мнением. Несправедливость прежнего социального порядка и свойственные ему отношения собственности обличаются революционерами якобы с позиций обездоленной народной 
массы, но стоит им самим оказаться у власти, как они восстанавливают институт собственности, хотя и в новом «издании», а массам стараются вернуть уважение к этому институту как «преобразованному», поставленному на службу развития и новых общественных интересов: «Устанавливаются сильнейшие тормозные стимулы: штрафы, аресты, тюрьмы, смертная казнь. Общество лечат огнем и железом. На разбушевавшиеся импульсы собственности накладывается узда» [Сорокин 2005, с. 105].

Но действительно ли проблема собственности - отличительная черта любой революции? Сравнивая революции в различных странах, Сорокин вынужден был признать: в некоторых случаях, например, в революциях 1830 и 1848 гг. во Франции, революции 1848 г. в Германии «процессы растормаживания этих рефлексов были неглубоки» [Сорокин 2005, с. 118]. Сорокин подчеркивал, что разные революции ставят перед собой несхожие цели и развиваются по различным сценариям. Вопросы собственности становятся во главу угла только в тех революциях, в которых реализуется левая программа преобразований, а революции, которые выдвигают иные цели, например, смену политического строя, могут обходить проблему собственности стороной или затрагивать лишь в отдельных малозначащих пунктах политической программы.

Ожесточенная защита Сорокиным институтов собственности может показаться странной читателю, знакомому с его биографией, поскольку, будучи одним из руководителей партии эсеров, он должен был разделять и поддерживать ее программу грядущих преобразований в России, включая обобществление земель, справедливую, равную раздачу земельных наделов крестьянам. Реализовать подобную программу без насильственного изъятия собственности у ее прежних владельцев не представлялось возможным. Надо ли это понимать так, что, находясь в эмиграции, Сорокин изменил своим прежним взглядам или же он всегда выступал за сохранение собственности в руках крупных владельцев, а партию эсеров и ее политический манифест использовал только как социальный лифт, помогающий сделать политическую карьеру? Можно лишь предполагать, что многое из сказанного им вскоре после того, как он выехал из России, имело не столько научный, сколько политический смысл. Позднее, в работах, посвященных культурной и социальной динамике, Сорокин отошел от политической конъюнктуры, заявив идею социетальных интегральных циклов, через которые проходят общества в разные периоды своей истории. Идеациональная фаза цикла характеризуется упором на ценности, в ней мир «горний» господствует над миром вещей, а собственность рассматривается либо как обременение, либо, как в известной работе М. Вебера, условие спасения. Иными словами, в работах общего характера Сорокин готов был признать, что на разных этапах своей эволюция институт собственности имеет различную степень значимости и несхожие пути трансформации.

Речь идет об институте, задача которого заключается в регулировании социальных отношений, когда любое перераспределение происходит с участием государства и часто по тем сценариям, которые им определяются. В сложных обстоятельствах, вызванных, в частности, войнами или народными волнениями, государство ведет себя иначе, чем в обычное время, и довольно часто прибегает к ограничениям операций с собственностью или установлению над ней фактического контроля. В условиях назревающей революции (и в этом Сорокин, 
безусловно, прав) невозможна рутинная работа социальных институтов, но виной тому не столько революция, сколько нерешенные проблемы предшествующего периода, вопиющее неравенство и несправедливость дореволюционной российской жизни, помноженные на тяготы военного времени. Один из серьезных исследователей революционной ситуации Чарльз Тилли подчеркивал, что именно войны создают ту зыбкую почву, на которой формируются предпосылки революции, при этом поражения в войнах ослабляют правительство, размывают легитимность действующей власти. Немаловажно и то, что в условиях войны в обществе накапливается большое число вооруженных людей, готовых при случае обратить оружие против своих политических конкурентов. Теряющее силу государство не в состоянии подавить политические группы (polities), выдвигающие альтернативные программы глубинных преобразований: «Резкое ослабление репрессивных возможностей государства вследствие войны, измены или какой-либо другой катастрофы может одновременно создать возможности для революции и вдохновить революционеров на выступление. Французская революция 1870 г., последовавшая вскоре после поражения Франции в войне с императором Пруссии, находится в этой категории» [Tilly 1978, p. 209]. В результате к власти приходят партии крайностей, настроенные на радикальные трансформации действующих институтов, включая институт частной собственности. Собственность, принадлежавшая классам, сходящим со сцены, либо присваивается революционным государством, либо передается верным режиму лицам, либо обобществляется.

В двух русских революциях вопрос о собственности упирался в слабость российской буржуазии, которая теснейшим образом была связана с государством, питавшейся его бюджетом, и в нерешенность вопроса о земле, значительная часть которой по-прежнему находилась в руках крупных латифундистов. Свою интерпретацию причин русской революции дала американский социолог Теда Скочпол: «Какие условия вели Россию к аграрной революции? Дворянство, находившееся в состоянии политического и экономического упадка, контролировало значительные земельные ресурсы в сельских районах. Ему удавалось удерживать крестьян в отношениях откровенной эксплуатации, бесполезных с функциональной точки зрения, служащих лишь одной цели - позволять дворянам вести жизнь рантье. В то же время институты коллективного управления крестьянских общин стали в политическом отношении более независимыми. Экономическое давление на крестьян усиливалось, но технологии производства сельхозпродукции были по-прежнему отсталыми. Программа индустриализации Витте, приведшая к повышению налогов, совпала с общим кризисом в сельском хозяйстве, сделавшим положение крестьян отчаянным. После 1890 года волнения среди крестьян усилились, хотя и безжалостно подавлялись властями» [Skocpol 1979, p. 132]. T. Скочпол полагает, что при росте социальной напряженности революцию сдерживал только репрессивный аппарат, который терял эффективность в период войн 1905 и 1917 гг. С ее точки зрения, ситуация обострялась вследствие архаичной, затрудняющей развитие системы землевладения, поэтому один из ключевых вопросов, который стоял в повестке дня революции, касался института собственности - собственности на землю и принципов ее распределения. Не рефлексы жадности и безудержного присвоения, а назревшая необходимость покончить с вопиющим неравенством направляла логику революционеров, стремящихся к «черному переделу». 


\section{Нравственный кризис}

Сорокин полагал, что революция имеет негативное, разлагающее влияние на общественную мораль. Кризис институтов, спровоцированный революцией, приводит, считал он, к разгулу полового инстинкта, потере населением представлении об общественной норме в сфере отношения полов: «Революция, объявляя многих из таких тормозов “суевериями” и “буржуазными предрассудками”, тем самым очень часто разрушает их. <..> К тому же результату ведет она и прямо - изменением норм семейно-брачного права. Этому же благоприятствует и дикая революционная борьба, непосредственно стимулирующая половые центры, причем иногда ее влияние усиливается и чрезмерным потреблением крепких спиртных напитков» [Сорокин 2005, с. 119].

Свобода половых отношений, провозглашаемая революцией, констатировал Сорокин, ведет к увеличению количества разводов и одновременно к росту числа внебрачных детей. Эти явления набирают силу на фоне духовного кризиса, отказа значительной части населения от традиционной веры и заповедей, укрепляющих социальную жизнь: «Гаснут те религиозно-морально-правовые рефлексы, которые тормозят убийства и посягательство на здоровье и телесную неприкосновенность. Говоря языком уголовного права, колоссально возрастают преступления против личности. Заповедь “не убий” перестает соблюдаться и признаваться. Там, где проходит Революция, дорога устилается трупами, искалеченными людьми, покрывается потоками крови. Ценность человеческой жизни низводится до нуля» [Сорокин 2005, с. 137]. И в этом случае Сорокин имел в виду, прежде всего, российскую революцию и ее последствия для общества: речь идет о снятии нравственных барьеров в обществе, где господствуют патриархальные нормы и ценности. Раскованность начального периода революции сменяется усилением контроля над частной сферой, восстанавливаются ослабленные или разрушенные революцией институты - брак, семья, общественная мораль. Анализируя последствия революции в области морали, Сорокин старательно обходил вопрос о том, способна ли она производить долговременные эффекты или ее влияние распространяется только на ограниченный период стихийных народных возмущений. Если речь идет только о кратком помутнении рассудка, то сказанное Сорокиным более чем справедливо, но если последствия революции прочитываются не только в короткой, но и длительной перспективе, то тогда вопрос представляется более сложным. Необходимо понимать, каковы эти долговременные последствия и есть ли в них положительные аспекты. Даже если обратиться к излюбленному Сорокиным «идеальному типу» революции - российской революции 1917 г., ее последствия в сфере общественных нравов были далеко не так однозначны, как об этом писал Сорокин. Новая власть запустила процесс эмансипации женщин даже более смелый, чем все попытки уравнять женщин в более развитых странах Запада: женщины в массовом порядке вовлекались в управление, производство, образование. Проект социального равенства не был свободен от изъянов, но он создал, например, институциональные заделы, помогавшие устранять наиболее грубые формы дискриминации полов, свойственные традиционным, патриархальным обществам: «К 1929 году женщины составляли $27,2 \%$ всего работающего населения (включая все виды занятости). Статистические данные не дают возможности оценить качественные 
изменения занятости женщин. В постреволюционный период предпринимались попытки, несмотря на нехватку финансирования, создавать новые возможности включения женщин-рабочих в социальную жизнь и культуру и вовлекать женскую рабочую силу, особенно молодых женщин, в различные образовательные программы. В этот период женщины фигурировали в ряде законов, регулирующих сферу труда, акцентировавших особенности их физиологии, ограничивавших их занятость на рабочих местах в промышленности с наиболее тяжелыми условиями» [Ilič 1999, p. 33].

\section{Динамика революции}

Сорокин видел в революции период безвременья и распада, которые приходят на смену социальному порядку; революция, по выражению Сорокина, поднимает со дна социальную муть, путает социальные координаты, рушит сложившиеся иерархии. Для Сорокина революция - это состояние коллапса, в котором общество не может пребывать долго. Вызываемые ею состояния сферы общественных отношений патологичны, поэтому возвращение к природной социальной норме, то есть социальному порядку, неизбежно. Для того чтобы восстановить его, революционная власть должна измениться и предать первоначальные идеалы безграничной свободы, регенерировать власть социальных рефлексов над поведением. Сорокин констатировал: за периодом революционного подъема неизменно следует термидор, террор, цель которого заключается в том, чтобы вернуть в общество страх перед властью, уважение к собственности и приемлемые для общества нормы поведения. Революционный период в целом включает в себя три фазы - фазу яростной атаки на институты старого порядка, фазу революционных изменений и, наконец, фазу термидора, террора, которые цементируют основы новой власти. В отличие от К. Маркса, учение которого он отвергал, Сорокин концентрировал внимание только на циклах разрушения и восстановления, отказываясь признавать за революцией хотя бы какое-то позитивное начало. В описании русской революции он обходит вниманием ее достижения: разрушение сословных перегородок, ускоренную восходящую мобильность для тех слоев общества, которые при старом порядке не имели ни малейших шансов возвышения, включение широкой массы населения в процессы преобразования в духе Просвещения.

Концепция революции, выдвинутая Сорокиным, претендовала на универсальность и прогностическую силу, но оказалась пригодной, да и то с оговорками, только для описания социальных революций определенного типа, и русской революции прежде всего. Между тем в исторической перспективе революции далеко не всегда приводили к массовому насилию и крушению действующих институтов: американская революция 1775 г. имела антиколониальный вектор, проходила под лозунгами свободы, просвещения и прав человека. В новейшей истории примером этому могут служить и революции 1950-1960-е гг. в развивающихся странах, исход которых определялся локальной спецификой: в одних случаях на волне революционных изменений власть захватывали военные, стремившиеся установить жесткий режим подавления оппозиционных сил; в других случаях, например, 
в Индии, политические силы национальной ориентации сохраняли многие из институтов, возникших в колониальную эпоху ${ }^{3}$.

В конце 1980-х гг. возник термин «бархатная революция», который означал радикальные социальные и политические трансформации в странах Восточной Европы, приведшие к независимости, переходу к рыночным формам хозяйствования, восстановлению демократических институтов. Во всех названных случаях удалось обойтись без фазы термидора, массовых жертв, раскрепощения нравов и экономического упадка: глубина перестройки социальных и политических институтов хотя и была значительной, но при этом революционеры не стремились к массовым репрессиям, позволяя представителям левой оппозиции участвовать в выборах и даже иногда одерживать в них победу. Биологизируя проблему, Сорокин намеренно ушел от обсуждения важного вопроса структурных посылов революции, которые анализировали К. Маркс и его последователи, в частности, упоминавшаяся выше Т. Скочпол. Следует подчеркнуть невозможность сравнения революций в аграрных обществах с развитыми авторитарными традициями и низкой ценностью человеческой жизни, с одной стороны, с революциями, пусть даже и социальными, в современных, урбанизированных обществах, опирающихся на массовый средний класс и отстроенную систему низовой демократии, с другой. Это признавал и сам Сорокин, констатируя, что в некоторых случаях революции избегали массовых репрессий, сохраняя ядро институциональной системы.

Важный вопрос идеологии, направляющей революционные силы, был, по сути, обойден Сорокиным, который полагал, что стихия революции является самодовлеющей, определяя, вопреки благим пожеланиям ее лидеров, действия социальных сил, вовлеченных в процесс преобразований. Между тем опыт XX столетия свидетельствует о том, что идеология имеет значение и что именно она устанавливает рамки, в которых действуют силы, выступающие за изменения. Идеология играет важную функцию поиска настоящих смыслов и целей революции, определяя своих сторонников. Рассуждая об идейной подоплеке революции, Майкл Уолцер проводит аналогии между ней и библейским сказанием об исходе - мистерии, которая разыгрывается каждый раз, когда народные массы восстают против старого порядка [Walzer 1985]. С его точки зрения, любая революция это движение между начальной и конечной точкой, которой является обетованный мир свободы, и без настоящей идеи, способной мобилизовать значительную часть населения, пройти этот путь невозможно. Как и библейский исход, революция несет в себе опасность жертв, жестокостей и соблазнов: она не всегда приводит массы в ту «землю», которая удобна и комфортна для строительства нового мира. При этом «земля», в которую в конечной фазе революции приходит общество, это не восстановление утраченных рефлексов, а новое состояние и новые перспективы развития.

В рассуждениях о революции Сорокин справедливо концентрировал внимание прежде всего на внутренних, эндогенных последствия восстания против существующего порядка. Опыт революций в XX и XXI вв. говорит о том, что только в редких случаях разрушение социального порядка обходится без вмешательства

\footnotetext{
3 Индийская освободительная революция шла под лозунгами демократии, полной эмансипации угнетенных слоев населения, равенства и отмены архаичной кастовой системы.
} 
извне - вмешательства в разных формах, включая помощь революционерам или, напротив, противодействие им. Стихийное перерастание русской революции в радикальную фазу случилось главным образом потому, что Временное правительство, в которое Сорокин входил в качестве секретаря А.Ф. Керенского, настаивало на соблюдении Россией обязательств перед союзниками, на продолжении войны, утратившей в глазах значительной части населения всякий смысл и остававшейся источником крайних страданий и потерь. Предметом обсуждения историков стали факты участия английской разведки и немецкого Генштаба в подготовке русских революций 1917 г. В подобных обсуждениях часто фигурируют сомнительные факты и недоказанные мотивы, но отрицать полностью всякое влияние внешних сил на ситуацию в ослабленной России означало бы игнорировать важную составляющую развернувшейся в стране политической борьбы.

Критика Сорокиным революции изобилует жесткими, эмоционально заряженными определениями. Он вместе со своими предшественниками и последователями рассматривал революцию как кризис нравов, как социальный катаклизм, одной из причин которого становится «народное заблуждение». Не только политики, но и весь народ - русский в период революции 1917 г., французский в период Великой французской революции - давали себя увлечь водовороту порока и насилия, истребляли лучшую свою часть (аристократию, интеллигенцию), питали собственное воображение ложными надеждами, переставали жить подлинной жизнью, подменяя ее несбыточными надеждами на будущий идеальный порядок. Как и многие российские интеллигенты, Сорокин готов был приравнять революцию к отказу народа от своего истинного призвания. В основе подобного отношения лежит свойственное российскому образованному классу патронирующее отношение к народной массе, которая видится ему иррациональной, неразумной, легко уступающей стихии безусловных рефлексов. Рано или поздно народная масса возвращается к прежнему управляемому состоянию, но происходит это за счет масштабного насилия, а новая власть оказывается более жестокой и циничной, чем тот режим, который она успешно сокрушила руками толпы. В концепции революции, которую продвигал Сорокин, политическая игра присутствует как «разборки» верхов, использующих население исключительно в качестве инструмента продвижения собственных интересов. О заблуждениях, просчетах и преступлениях прежней власти, о том, какие ее шаги систематически повышали градус социальной напряженности, Сорокин старался не говорить: акцент критики в его рассуждениях был смещен с причин на следствия, с нарастающего недовольства политикой прежнего режима на чудовищные преступления, которые творил новый режим, отчасти потому, что желал обуздать стихию революционного порыва. Сводя дело к рефлексам, Сорокин, вопреки собственному желанию, оправдывал новую власть, стоявшую перед трагическим выбором между насилием и полным распадом, концом истории для одного конкретного общества. В этой ситуации без жестких мер обойтись невозможно и все жестокости, бессмысленные на первый взгляд, служили целям устрашения народной массы, потерявшей нравственные ориентиры. Большевики, если придерживаться подобной точки зрения, лишь исправляли ошибки, которые были допущены старым режимом, его коррумпированной верхушкой.

Публицистичность концепции Сорокина, безусловно, была связана с его желанием свести счеты со своими политическими оппонентами и одновременно утвердить себя в роли критика красной революции в России и левых движений 
на Западе. Его идеи были благосклонного приняты противниками большевизма по обе стороны океана. В своем письме Н.Е. Шаповалову от 17 июня 1925 г. Сорокин не скрывал своего удовлетворения: «Моя “Социология революции" нашла прекрасный прием и в общей печати, и у специалистов. Из ряда статей и рецензий о ней я знаю лишь одну “холодную”. Все остальные - очень положительны. Ряд подписанных особенно крупными учеными, например, проф. Abbot'oм из Гарвардского университета - он считается самым крупным историком по истории Америки - восторженны: Abbot поставил работу выше работ таких [ученых], как Тэн или Лебон. Даже пробольшевистская “Nation” только что напечатала вполне положительную рецензию проф. Barnes’a. Ross, Ellwood, Cooley, Bogardus, Paten и другие социологи и психологи прислали мне и издателю весьма похвальные отзывы. New York Times, Boston Transcript, Saturday Review of Literature, Review of Review, Journal of Applied Sociology и т.д. дали статьи и отзывы очень положительные. Словом, я вполне удовлетворен, хотя я сам знаю многие недочеты книги, вызванные главным образом тем, что в Праге не было массы нужных книг» (цит. по [Сапов 2015, с. 32]). Можно предположить, что именно политическая позиция позволила Сорокину сделать карьеру в американских университетах восточного побережья США, где левые движения и левые идеи традиционно находились под подозрением. Американским социологам старшего поколения не могло не понравиться то, что бывший социалистреволюционер из России, оказавшись в США, энергично выступает в защиту американской экономической элиты и готов спорить с Торстайном Вебленом, выдвинувшим не слишком комплиментарную по отношению к ней концепцию праздного класса.

Сыграв свою разоблачительную роль, работа Сорокина потерялась на фоне потрясений и войн послереволюционной эпохи. Настало время других революций и других работ, анализирующих их причины. В глазах многих европейских и американских интеллектуалов русская революция, несмотря на все ее жертвы и критику со стороны многочисленных отечественных и зарубежных исследователей, сохранила за собой статус дерзкого социального эксперимента, изменившего судьбы мира. Свою концепцию Сорокин строил, взяв за образец революцию с левой программой, но мир уже вступал в тот напряженный период, когда левая идея вошла в беспощадный конфликт с расистскими, националистическими лозунгами набиравшего силу фашизма, когда в Европе забрезжили революции с иными, отнюдь не универсалистскими лозунгами, а немецкий консерватор Эрнст Юнгер призывал революцию «исполнить традицию», разрушая все, что мешает ее подлинному воплощению в народном духе [Юнгер 2008]. Надо сказать, что теория революции Сорокина была довольно холодно встречена в эмигрантской среде: неприятным сюрпризом для него стала критическая статья в «Воле России», подписанная неким Репейниковым, который на поверку оказался его старинным приятелем Д.А. Лутохиным. Как это типично, возмущался Сорокин, для российско-беспардонно-интеллигентского перекати-поле [Сапов 2008, с. 32]. Особенно задело его то, что Д.А. Лутохин обвинил его в «продаже капиталистам», то есть, по сути, в измене своим прежним левым идеалам. Философ Ф.А. Степун, с нетерпением ожидавший выхода «Социологии революции», отозвался о работе Сорокина без особого почтения как о работе «очень научно несолидной, но публицистически страстной» [Cапов 2008, с. 32]. 
Сегодня подзабытые на Западе работы Сорокина, посвященные революции, возвращаются в оборот научный мысли России, предоставляя, с одной стороны, возможность более глубокого понимания событий столетней давности, а с другой, напоминая о том, что в нашей стране революция - это не только история: это еще и запасной «объездной» маршрут в будущее на тот случай, если российская власть окончательно «окуклится» в оболочке корыстных интересов и окажется неспособной ответить на вопросы, которые ставит перед ней российское общество.

\section{Литература}

Дойков Ю.В. (2008) Питирим Сорокин. Человек вне сезона. Биография. Архангельск.

Достоевский Ф.М. (1973) Братья Карамазовы. Роман в четырех частях с эпилогом. М.: Художественная литература.

Кнаубе Ю. (2016) Макс Вебер на рубеже двух эпох. М.: Дело.

Рубанов Б.Л. (2003) Философия лимитизма К.Ф. Жакова. К вопросу об истоках социологии П.А. Сорокина // Социологические исследования. № 7. С. 109-119.

Сапов В.В. (2015) Идол революции // Сорокин П.А. Листки из русского дневника. Социология революции. Сыктывкар: Анбур. С. 7-43.

Сорокин П.А. (1992) Дальняя дорога. Автобиография. М.: Терра.

Сорокин П.А. (2005) Социология революции. М.: РОССПЭН.

Сорокин П.А. (2006) Социальная и культурная динамика. М.: Астрель.

Сорокин П.А. (2015) Листки из русского дневника. Сыктывкар: Анбур.

Токвиль А. (2008) Старый порядок и революция. М.: Алетейя.

Юнгер Э. (2008) Националистическая революция. Политические статьи 1923-1933 гг. М.: Скименъ.

Ямпольский М. (2009) Революция как событие смысла // Прохорова И., Дмитриев А., Кукулин И., Майофис М. (ред.) Антропология революции. М.: Новое литературное обозрение. С. $17-53$.

Beetham D. (1985) Max Weber and the Theory of Modern Politics, Cambridge: Polity Press.

Foran J. (1997) Theorizing Revolutions, L.: Routledge.

Ilič M. (1999) Women Workers in the Soviet Interwar Economy: From "Protection" to "Equality", L.: Palgrave MacMillan.

Sewell W. (1980) Work and Revolution in France: The Language of Labor from the Old Regime to 1848 , Cambridge: Cambridge University Press.

Skocpol T. (1979) State and Social Revolutions. A Comparative Analysis of France, Russia and China, Cambridge: Cambridge University Press.

Tilly Ch. (1978) From Mobilization to Revolution, N.Y.: Random House.

Timasheff N.S. (1963) Sorokin on Law, Revolution, War, and Social Calamities // Pitirim Sorokin in Review (ed. Alien P.A.), Durhem, N.C.: Duke University Press, pp. 247-275.

Walzer M. (1985) Exodus and Revolution, N.Y.: Basic Books. 


\title{
Pitirim Sorokin and His Theory of Revolution
}

\author{
M. CHERNYSH*
}

\begin{abstract}
*Mikhail Chernysh - Doctor of Science in Sociology, Deputy Director, Institute of Sociology, Russian Academy of Sciences. Address: bld. 5, 24/35, Krzhizhanovskogo St., Moscow, 117218, Russian Federation. E-mail: che@isras.ru

Citation: Chernysh M. (2017) Pitirim Sorokin and His Theory of Revolution. Mir Rossii, vol. 26, no 4, pp. 71-96 (in Russian). DOI: 10.17323/1811-038X-2017-26-4-71-96
\end{abstract}

\section{Abstract}

Russo-American sociologist Pitirim Sorokin summarized his impressions of the February and October revolutions in several of his works. In his autobiography "A Long Journey" he remembered how he joined the revolutionary movement, became a member of the socialistrevolutionary party, and agitated workers and peasants to overthrow the Tsarist regime. After the February revolution triumphed over the old regime Sorokin turned into an active supporter of the Interim government and served as secretary to its head, Alexander Kerensky. He reflected on his impressions of the revolution not only in his autobiography, but also in his notes about the developments of 1917 - the gradual groundswell of chaos and the collapse of the social order. In his "Sociology of Revolution" Sorokin made an attempt, possibly one of the first, to use the Russian revolution as the basis for his own theory of revolution. In constructing this theory he relies on the theory of conditional and unconditional reflexes that he regards as a new way in understanding the nature of human action. He believes that in the revolutionary period society enters a phase when conditional reflexes, which are instrumental to maintaining social order, lose their controlling influence. The social order collapses ceding its place to the chaotic, destructive biological reflexes. The process leads to a deep crisis in social institutions which are reproduced through "learning" ways of behavior necessary to sustain social life. As a result, society faces the malfunctioning of reflexes which secure obedience to authority, and which allow a collapse of the motivation to work, a critical growth of crime rates and other attacks on law and order. The social reflexes which maintain the value of human life decline dramatically opening the way to a dramatic rise of crime against individuals. The morals which regulate sexual behavior are made void by revolutionary chaos and the ensuing sexual promiscuity provokes a crisis in family relations. Revolutionary chaos undermines the reflex which guides the division of property into "mine" and "not mine", thereby weakening the institution of private property and enabling criminal elements to confiscate citizens' property under the threat of death. However, the chaos brought about by the revolution has its limits. The final phase of a revolution brings to power forces that seek to restore social order by any means possible. This results in a dictatorship that uses coercion and indiscriminate violence to bring society to order. Sorokin's theory received positive appraisal from his US colleagues. However, in Europe and in the milieu of Russia émigrés it was mainly regarded as an anti-Bolshevik manifesto that had no serious scientific value. Sorokin's theory portrayed revolution as 
an event taken out of its historical context without any significant link with the policies of the previous regime and with no full regard of the consequences which were not only destructive, but also in a way positive. Nevertheless, whatever its deficiencies Sorokin's theory is still relevant for Russian sociology. It is an important testimony describing crucial events of the past and a critique of the Russian inclination for "historicism" - a desire to find answers to complex questions in the violent change of power.

Key words: social change, revolution, power relations, property and ownership, integral theory

\section{References}

Beetham D. (1985) Max Weber and the Theory of Modern Politics, Cambridge: Polity Press.

Dojkov Yu.V. (2008) Pitirim Sorokin. Chelovek vne sezona. Biografiya [Pitirim Sorokin. A Man out of Season. Biography], Archangelsk.

Dostoyevsky F.M. (1973) Brat'ya Karamazovy. Roman $v$ chetyrekh chactyakh s epilogom [The Karamazov Brothers. A Novel of Four Parts With an Epilogue], Moscow: Khudozhestvennaya Literatura.

Foran J. (1997) Theorizing Revolutions, L.: Routledge.

Ilič M. (1999) Women Workers in the Soviet Interwar Economy: From "Protection" to "Equality", L.: Palgrave MacMillan.

Jünger A. (2008) Natstionalisticheskaya Revolyutsia. Politicheskie stat'i 1923-1933 [Nationalist Revolution. Political Articles 1923-1933], Moscow: Skimen'.

Knaube Yu. (2016) Maks Weber na rubezhe epokh [Max Weber at the Edge of Epochs], Moscow: Delo.

Rubanov B.L. (2003) Filosofiya limitizma K.F. Zhakova. K voprosu ob istokakh sotsiologii P.A. Sorokina [The Philosophy of "Limitism" of K.F. Zhakov. Sources of Pitirim Sorokin's Sociology]. Sotsiologicheskie issledovaniya, no 7, pp. 109-119.

Sapov V.V (2015) Idol revolyutsii [The Idol of the Revolution]. Sorokin P.A. Listki iz russkogo dnevnkika. Sotsiologiya revolyutsii [Pages from a Diary. Sociology of Revolution], Syktyvkar: Anbur, pp. 7-43.

Sewell W. (1980) Work and Revolution in France: The Language of Labor from the Old Regime to 1848, Cambridge: Cambridge University Press.

Skocpol T. (1979) State and Social Revolutions. A Comparative Analysis of France, Russia and China, Cambridge: Cambridge University Press.

Sorokin P.A. (1992) Dal'naya doroga. Avtobiografiya [A Long Journey. Autobiography], Moscow: Terra.

Sorokin P.A. (2005) Sotsiologiya revolyutsii [Sociology of Revolution], Moscow: ROSSPEN.

Sorokin P.A. (2006) Sotsial'naya I kul'turnaya dinamika [Social and Cultural Dynamics], Moscow: Astrel'.

Sorokin P.A. (2015) Listki iz russkogo dnevnkika. Sotsiologiya revolyutsii [Pages from a Diary. Sociology of Revolution], Syktyvkar: Anbur.

Tilly Ch. (1978) From Mobilization to Revolution, N.Y.: Random House.

Timasheff N.S. (1963) Sorokin on Law, Revolution, War, and Social Calamities. Pitirim Sorokin in Review (ed. Alien P.A.), Durhem, N.C.: Duke University Press, pp. 247-275.

Tocqueville A. (2008) Staryj poriyadok i revolutsiya [The Old Regime and Revolution], Moscow: Alateya.

Walzer M. (1985) Exodus and Revolution, N.Y.: Basic Books.

Yampol'skij M. (2009) Revolyustiya kak sobytie smisla [Revolution as an Event of Meaning]. Atropolpogiya revolyutsii [Anthropology of Revolution] (eds. Prokhorova I., Dmitriev A., Kukulin I., Majofis M.), Moscow: New Literary Observer Publishing House, pp. 17-53. 